University of Nebraska - Lincoln

DigitalCommons@University of Nebraska - Lincoln

October 2000

\title{
The Consequences of Forced CEO Succession for Outside Directors
}

Kathleen A. Farrell

University of Nebraska Lincoln, kfarrell2@unl.edu

David Whidbee

Washington State University

Follow this and additional works at: https://digitalcommons.unl.edu/cbafacpub

Part of the Business Commons

Farrell, Kathleen A. and Whidbee, David, "The Consequences of Forced CEO Succession for Outside Directors" (2000). College of Business Faculty Publications. 5.

https://digitalcommons.unl.edu/cbafacpub/5

This Article is brought to you for free and open access by the Business, College of at DigitalCommons@University of Nebraska - Lincoln. It has been accepted for inclusion in College of Business Faculty Publications by an authorized administrator of DigitalCommons@University of Nebraska - Lincoln. 


\section{The Consequences of Forced CEO Succession for Outside Directors*}

\section{Introduction}

Fama (1980) and Fama and Jensen (1983) argue that outside directors have an incentive to be effective monitors to signal to shareholders and labor markets their value as directors. Recent empirical evidence confirms that outside directors, in some circumstances, perform an important monitoring function (Brickley and James 1987; Weisbach 1988; Byrd and Hickman 1992; and Brickley, Coles, and Terry 1994). At the same time, however, Mace (1986) and Jensen (1993) argue that outside directors are not effective monitors of senior managers because they have little incentive to remove a poorly performing CEO. ${ }^{1}$

The conflicting arguments about the incentives

* We would like to thank Anthony Clarke and Jeremy Brown for their research assistance. We appreciate the helpful comments and suggestions of Sam Allgood, David Blackwell, Beth Cooperman, Claire Crutchley, John Geppert, Stan Hoi, Gordon Karels, Leslie Levy, Herman Manakyan, George McCabe, Myra Moore, Jeff Netter, Rick Sias, Tom Zorn, and an anonymous referee. David Whidbee appreciates the financial support provided by the California State University, Sacramento, Research, Scholarship and Creative Activities Award program. Kathleen Farrell appreciates receiving partial support from the 1996 Hicks Foundation Summer Research Grant. We are responsible for all errors in the manuscript.

1. See Jensen (1993) and the Wall Street Journal article by Lublin and Duff (1995) for examples of corporate boards that failed to remove a poorly performing CEO.

(Journal of Business, 2000, vol. 73, no. 4)

(C) 2000 by The University of Chicago. All rights reserved. 0021-9398/2000/7304-0004\$02.50
We find an increased likelihood of outside director turnover following forced CEO succession, especially among those directors that are closely aligned with the outgoing $\mathrm{CEO}$, own little equity, and make poor replacement decisions. Directors that remain on the board, however, are more likely to acquire new directorships than those that remain on the board of a matched-sample firm. Overall, the results suggest that outside directors who are not aligned with the CEO and own relatively large equity stakes are rewarded when they remove a poorly performing CEO and replace him or her with a CEO that improves firm performance. 
confronting outside directors are difficult to test empirically because of the difficulty in establishing a relation between board effectiveness and the incentives faced by outside directors. Removing a poorly performing CEO, however, is one of the most observable signals that outside directors can send to shareholders and labor markets about their effectiveness as directors. Fama and Jensen (1983) argue that outside directors' principal compensation for serving on corporate boards is in the form of the reputation they develop as expert monitors of managers. Therefore, the incentives they face are related to their continued service on the board and their opportunities for additional directorships.

We analyze the incentives confronting outside directors by examining the consequences of firing a CEO. If directors are rewarded by the director labor market for removing a poorly performing CEO, we would expect to observe an increase in the number of other directorships they hold and a lower (or at least unchanged) probability of departure from the current board. On the other hand, if directors suffer adverse consequences for forcing CEO turnover, we would expect to observe a decrease in the number of other directorships held and a higher probability of departure from the current board.

Using a sample of 66 forced CEO turnovers between 1982 and 1992, we compare 540 outside directors that forcibly remove their CEOs to 576 outside directors from a matched sample that do not forcibly remove their CEOs. ${ }^{2}$ Because the primary objective of this study is to analyze the consequences of removing an incumbent CEO, we examine whether the directors that force CEO turnover are more likely to leave the board than the matched-sample directors. In addition, we examine the number of other directorships gained or lost by the directors that force CEO turnover relative to the matched-sample directors.

An additional objective of this study is to examine the characteristics of individual directors that benefit (remain on the board or acquire additional directorships) from the forced removal of the CEO and those that suffer adverse consequences (leave the board or lose other directorships). The corporate governance literature identifies several director and firm characteristics associated with increased board effectiveness. These characteristics include, for example, small board size (Yermack 1996; Eisenberg, Sundgren, and Wells 1998), director share ownership (Shivdasani 1993), and director independence (Weisbach 1988). We shed additional light on whether these same director and firm character-

2. We define forced turnover as a turnover that occurs due to pressure by the board of directors, management shakeup, resignation, firing, or poor performance as described in the Wall Street Journal. Our matching criteria restrict the matching firms to firms that do not experience forced turnover over a 5-year period surrounding the turnover date. The matching firms include 28 firms that experience voluntary turnover and 38 firms that experience no turnover. 
istics are associated with the penalties or rewards experienced by outside directors that remove a poorly performing CEO.

The results suggest that although outside directors that force CEO turnover are more likely to leave the board, some directors benefit from the forced removal of the CEO. The directors that hold large equity stakes, are not closely aligned with the outgoing CEO, and make good CEO replacement decisions are more likely to acquire additional directorships and less likely to suffer the same adverse consequences as other directors that force CEO turnover. The ex post rewards offered to these directors suggest that some directors have an incentive to remove a poorly performing CEO, consistent with the arguments made by Fama (1980) and Fama and Jensen (1983). However, the rewards seem to extend only to those directors that remain on the board of the forced turnover firm. Directors that leave the board tend to be those that were closely aligned with the outgoing CEO and own little of the firm's equity. These same directors are more likely to lose other directorships relative to the directors that remain on the forced turnover boards. Our results suggest that simply removing a poorly performing CEO is not sufficient to be rewarded in the market for their services as directors. Outside directors also need to make good replacement decisions.

Our results provide some support for Mace (1986) and Jensen's (1993) argument that directors have little incentive to remove a poorly performing CEO because they are faced with a higher probability of leaving the current board. We also find, however, that directors with characteristics associated with effective monitoring (e.g., independence from the CEO, substantial equity ownership, and sufficient decisionmaking expertise to make good replacement decisions) tend to be rewarded for removing a poorly performing CEO through a higher probability of remaining on the forced-turnover board and an increased likelihood of gaining an additional outside directorship.

The remainder of the paper is organized as follows. Section II describes the sample selection process and the data, including descriptive statistics for the firms and directors in the turnover and matched samples. Section III presents an analysis of the likelihood that a director leaves the board after CEO turnover. Section IV analyzes changes in the number of other directorships held by outside directors. Section V concludes the article.

\section{Sample Design}

\section{A. Selecting the Sample of Forced CEO Turnovers}

We identified a sample of 66 forced CEO turnovers using the Forbes Survey of Executive Compensation (hereafter Forbes) and the Wall 
Street Journal. We analyzed all firms that appeared in Forbes from 1981 to 1992 and documented CEO turnover using either Forbes or proxy statements. ${ }^{3}$ After excluding regulated firms and CEOs that were in office for less than 2 years, we investigated the reasons for the 545 remaining turnovers. ${ }^{4}$ We identified 107 forced CEO turnovers using the Wall Street Journal. ${ }^{5}$ A turnover is classified as forced if the article discussing the departure mentions pressure from the board of directors, resignation, scandal, reorganization, demotion, policy or personality disagreement, or poor performance. ${ }^{6}$ From the 107 forced turnovers, we lost 41 additional turnovers due to an inability to find an appropriate matching firm, missing proxy statements, or incomplete performance data on Standard and Poor's Annual Industrial Compustat. Any firms that were acquired within 4 years after forced CEO turnover were also excluded. The final sample consists of 540 outside directors associated with 66 forced CEO turnovers in 63 firms.

\section{B. Matched Sample}

To determine if the directors that force CEO turnover experience significant consequences in terms of their tenure on the board and the number of other directorships they hold, we create a matched sample of directors that do not force CEO turnover and satisfy the following criteria: (1) the matching firm operates in the same two-digit standard industrial classification (SIC) code as the forced-turnover firm $;^{7}$ (2) the matching firm's total assets are between $50 \%$ and $150 \%$ of the forcedturnover firm's total assets; (3) the matching firm's performance is comparable to the forced-turnover firm's performance, as measured by annual stock returns; and (4) the matching firm does not experience a forced turnover for 5 years surrounding the turnover date and was not acquired within 4 years after the turnover date of the forced-turnover firm.

3. Proxy statements were used to identify turnovers in firms that were not consistently listed in the Forbes survey.

4. We place these restrictions on the sample because regulated firms have been shown to be significantly different from industrial organizations (Baysinger and Zardkoohi 1986; Subrahmanyam, Rangan, and Rosenstein 1997). The 2-year restriction eliminates turnovers of interim CEOs.

5. The percentage of CEO turnovers that are classified as forced is $19.6 \%$ in our sample. Huson, Parrino, and Starks (2000) find that $20 \%$ of the 636 CEO turnovers in their sample that occur during the same period are forced. Studies by Denis and Denis (1995) and Warner, Watts, and Wruck (1988) find similar forced-turnover rates.

6. In defining forced departure, we use criteria similar to Blackwell and Farrell (1999), who combine the criteria used by Weisbach (1988), Gilson (1989), and Parrino (1997).

7. We use two-digit SIC codes to identify possible matches. The set of possible matches using three- or four-digit SIC codes would be too small when combined with our other matching criteria. In addition, Clark (1989) finds that SIC codes are more effective at dividing firms into broad industrial groups than at dividing firms into three- and four-digit segments to represent economic markets more closely. 
We use an industry- and size-matched sample to control for potential industry and size effects on director turnover and other directorships held by directors. Kaplan and Reishus (1990) argue that if outside directors are chosen for their industry expertise, matching companies by industry will control for the different opportunities for outside directorships available to managers in different industries. In addition, industry classifications may act as a proxy for growth opportunities. Booth and Deli (1996) find that growth opportunities are negatively related to the number of outside directorships held by CEOs. Parrino (1997) finds evidence that homogeneous industries have a higher incidence of outside CEO succession. He argues that firms in homogeneous industries require less firm-specific human capital and that the industry-specific human capital is transportable. Therefore, directors may have more opportunities available for additional directorships in homogeneous industries. DeFond and Park (1999) find that the frequency of CEO turnover is greater in highly competitive industries than in less competitive industries. These industry differences impacting CEO turnover may also apply to director turnover. The same arguments may be made for controlling for firm size.

Matching on performance controls for the empirical regularity that CEO turnover is negatively associated with firm performance. ${ }^{8}$ Matching on performance also controls for Kaplan and Reishus's (1990) finding that poorly performing managers hold fewer directorships than managers of other firms. It is worth nothing however, that Hermalin and Weisbach (1988) do not find any evidence that poor stock-price performance affects the likelihood of departure of outside directors.

After identifying all potential matched-sample firms using two-digit SIC codes and asset size, we compare the performance of the forcedturnover-sample firm to the performance of each potential matchedsample firm. Specifically, the average annual stock return during the 2 years prior to turnover for the forced-turnover-sample firm was compared to the average annual stock return over the same period for each of the potential matched-sample firms. Average annual stock returns were computed using the Center for Research in Security Price's (CRSP) daily returns file. The potential matched-sample firms were then ranked based on the absolute value of the difference in their performance and the turnover firm's performance, with those firms having the smallest difference being ranked first. We then selected the highest ranked firm that also satisfied the fourth criterion. We measure firm performance using stock returns rather than accounting measures of performance because accounting measures of firm performance do not

8. Coughlan and Schmidt (1985), Warner et al. (1988), and Parrino (1997), among others, document an inverse relationship between CEO turnover and firm performance. 
exhibit as much variation as stock returns (see, e.g., Allgood and Farrell 2000).

The turnover process itself may result in some restructuring of the board independent of the type of turnover. A new CEO may install his own board regardless of whether he is replacing a CEO that was forced out or a CEO that retired. To control for a general turnover effect, we identify firms in our matched sample that experience voluntary CEO turnover. ${ }^{9}$ If the consequences experienced by outside directors that force CEO turnover are simply due to CEO turnover, we should not find any significant differences between these directors and the directors of firms that experience voluntary CEO turnover.

\section{Data Collection for Board of Directors}

We collect board membership data from the last proxy statement filed in the 12 months prior to the forced-turnover date for the forced-turnover sample and the matched sample..$^{10}$ Based on this board membership, we track outside directors' board memberships 4 years after the CEO turnover for those directors remaining on the board by analyzing the proxy statement 5 years from the preturnover proxy date. We choose 5 years from the proxy statement preceding forced turnover because many boards of directors have three classes of directors with staggered 3-year terms. ${ }^{11}$ Consequently, within 4 years following turnover, the new CEO has had the opportunity to be involved in the election process of every member on the board.

Using proxy statements, we document the age, tenure as director, affiliation, other directorships, committee memberships, and equity ownership of each director prior to forced CEO turnover and 4 years following turnover for those that remain on the board. We do this for both the forced-turnover sample and the matched sample. ${ }^{12}$

In determining other directorships, we use the preturnover proxy

9. Step 4 in the matching process identifies whether a matching firm experiences CEO turnover during the 5 years surrounding the turnover date of the forced-turnover firm. By reading the Wall Street Journal announcement about the turnover, we determine whether the turnover was forced or voluntary in nature. This process identifies 28 matching firms that experience voluntary CEO turnover.

10. On average, the preturnover proxy statement predates CEO turnover by 6.25 months.

11. Thirty-seven of the 66 firms in the forced-turnover sample have 3-year staggered terms. Twenty-eight of the 66 matching firms have 3-year staggered terms.

12. In determining director affiliation, consistent with Weisbach (1988), Hermalin and Weisbach (1991), and Klein (1998), we place directors in one of three categories: inside directors, affiliated outside directors, or independent outside directors. Inside directors include corporate officers. Affiliated outside directors have a specified business relation with the firm, are retirees from the firm, or are related to a top officer. Affiliated outside directors include investment bankers, attorneys, commercial bankers that have made loans to the firm, consultants, officers and directors of the firm's suppliers and customers, and interlocking directors (the firm's board includes a CEO on whose board the firm's CEO serves). Independent outside directors have no affiliation with the firm other than their directorships. 
statements to identify the directorships held by a director prior to forced CEO turnover. We exclude directorships held with local banks, small local companies, and civic organizations (following Kaplan and Reishus 1990). We rely on several sources to identify directorships held by a director 4 years following forced CEO turnover. For directors remaining on the board, we obtain information on other directorships from the sample firm's proxy statement. For directors that leave the board, we search both the Standard \& Poor's Register of Corporations, Directors and Executives (hereafter $S \& P$ Register) and Lexis-Nexis. Volume 2 of the $S \& P$ Register provides detailed information on individual directors. ${ }^{13}$ Lexis-Nexis is an on-line database that allows us to search all electronically filed proxy statements for the names of individual directors.

The number of directorships gained and the number of directorships lost are determined by comparing the preturnover directorships to the postturnover directorships for those directors that remain on the board, those that are listed in volume 2 of the $S \& P$ Register, and those found in Lexis-Nexis. For those directors that leave the board and do not appear in either Lexis-Nexis or volume 2 of the $S \& P$ Register, we are not able to determine whether any directorships were gained. However, we are able to determine the number of directorships lost using volume 1 of the $S \& P$ Register. ${ }^{14}$

Sales, total assets, and market value of equity are measured as of the end of the year prior to CEO turnover for the forced turnover and corresponding matched-sample firms. Preturnover firm performance is measured using the average annual market-adjusted stock returns during the 2 years prior to turnover. ${ }^{15}$ Postturnover performance is measured using the average annual market-adjusted stock returns for 1 and 4 years following turnover.

\section{Analyzing the Matching of the Turnover Firms}

The financial, ownership, and corporate governance characteristics of the turnover and matched samples are shown in table 1. As expected, both samples perform poorly prior to the turnover date as indicated by market-adjusted stock returns. The forced-turnover sample, however, performed significantly worse than the matched sample as indicated by

13. Volume 1 of the $S \& P$ Register is an annual publication that identifies about 437,000 of the officers and directors of more than 75,000 corporations. Volume 2 provides detailed information on about 71,000 of the directors listed in volume 1 .

14. For example, Richard J. Flamson III served as a director of Allergan when the firm forced its CEO to resign. He also served on the board of Northrop Corporation. Flamson left the board of Allergan and could not be found using Lexis-Nexis or volume 2 of the $S \& P$ Register. Using volume 1 of the $S \& P$ Register, however, we were able to verify that Flamson also left the board of Northrop Corporation.

15. Stock returns are market adjusted using the CRSP NYSE/AMEX/NASDAQ valueweighted index. 
TABLE 1 Means and Tests for Differences in the Firms with Forced CEO Turnover and Matched Firms

\begin{tabular}{|c|c|c|c|}
\hline Variable & $\begin{array}{l}\text { Means for } \\
\text { Firms with } \\
\text { Forced CEO } \\
\text { Turnover }\end{array}$ & $\begin{array}{l}\text { Means for } \\
\text { Firms without } \\
\text { Forced CEO } \\
\text { Turnover }\end{array}$ & $t$-statistic ${ }^{\mathrm{a}}$ \\
\hline \multicolumn{4}{|l|}{ Preturnover financial characteristics: ${ }^{b}$} \\
\hline Sales (in billions of dollars) ${ }^{\mathrm{c}}$ & 3.523 & 3.058 & $1.723^{+}$ \\
\hline $\begin{array}{l}\text { Market value of equity (in billions of dol- } \\
\text { lars) }\end{array}$ & 2.791 & 2.271 & 1.226 \\
\hline $\begin{array}{l}\text { Average annual market-adjusted stock re- } \\
\text { turn }(\% ; 2 \text { years })^{\mathrm{d}}\end{array}$ & -12.27 & -7.56 & $-1.831^{+}$ \\
\hline $\begin{array}{l}\text { Average return on average assets }(\% ; 2 \\
\text { years) }\end{array}$ & 4.89 & 6.23 & -1.286 \\
\hline \multicolumn{4}{|l|}{ Preturnover ownership structure: } \\
\hline $\begin{array}{l}\text { Share ownership by inside directors of } \\
\text { the firm }(\%)\end{array}$ & 2.76 & 5.77 & $-2.055^{*}$ \\
\hline $\begin{array}{l}\text { Share ownership by affiliated outside di- } \\
\text { rectors }(\%)\end{array}$ & 1.13 & 1.17 & -.060 \\
\hline $\begin{array}{l}\text { Share ownership by independent outside } \\
\text { directors }(\%)\end{array}$ & 1.16 & 1.08 & .147 \\
\hline \multicolumn{4}{|l|}{ Preturnover corporate governance: } \\
\hline Board size & 11.9 & 12.3 & -.824 \\
\hline Inside-director board membership (\%) & 29.04 & 28.72 & .137 \\
\hline Affiliated-outsider board membership (\%) & 23.12 & 23.17 & -.021 \\
\hline $\begin{array}{l}\text { Independent-outsider board membership } \\
(\%)\end{array}$ & 47.84 & 48.10 & -.093 \\
\hline $\begin{array}{l}\text { Committee seats held by each inside di- } \\
\text { rector }\end{array}$ & 1.03 & .82 & 1.499 \\
\hline $\begin{array}{l}\text { Committee seats held by each affiliated } \\
\text { outsider }\end{array}$ & 1.85 & 1.63 & 1.427 \\
\hline $\begin{array}{l}\text { Committee seats held by each indepen- } \\
\text { dent outsider }\end{array}$ & 1.90 & 1.56 & $2.682 * *$ \\
\hline $\begin{array}{l}\text { Other directorships held by each inside } \\
\text { director }\end{array}$ & 1.03 & 1.14 & -.637 \\
\hline $\begin{array}{l}\text { Other directorships held by each affili- } \\
\text { ated outsider }\end{array}$ & 2.54 & 1.99 & $1.845^{+}$ \\
\hline $\begin{array}{l}\text { Other directorships held by each indepen- } \\
\text { dent outsider }\end{array}$ & 2.63 & 2.74 & -.632 \\
\hline CEO age (in years) & 59.1 & 58.0 & .890 \\
\hline CEO tenure (in years as a director) & 13.3 & 15.2 & -1.033 \\
\hline Average age for all directors (in years) & 59.5 & 59.1 & 1.074 \\
\hline Average tenure for all directors (in years) & 9.1 & 9.6 & -1.005 \\
\hline \multicolumn{4}{|l|}{ Postturnover performance: } \\
\hline $\begin{array}{l}\text { Average annual market-adjusted stock re- } \\
\text { turn after turnover }(\% ; 1 \text { year })^{\mathrm{d}}\end{array}$ & -.83 & -.53 & -.060 \\
\hline $\begin{array}{l}\text { Average annual market-adjusted stock re- } \\
\text { turn after turnover }(\% ; 4 \text { years })^{\mathrm{d}}\end{array}$ & -1.04 & -1.96 & .384 \\
\hline
\end{tabular}

NotE.-This table provides summary characteristics of 66 firms that forced CEO turnover during the 1982-92 period and a matched sample of 66 firms that did not force CEO turnover. Stock return data are from CRSP. Board of director data are from proxy statements. Other financial characteristics are from Compustat.

a The $t$-statistic tests the null hypothesis that the difference between the two sample means is zero. The $t$-statistic is based on paired comparisons between the two samples.

b Financial characteristics are measured as of the end of the year preceding turnover.

c Sales and market value of equity are expressed in constant 1990 dollars.

d Stock returns are market-adjusted using the CRSP NYSE/AMEX/NASDAQ value-weighted index.

+ Indicates that the difference in means is statistically significant at the $10 \%$ level

* Indicates that the difference in means is statistically significant at the 5\% level.

** Indicates that the difference in means is statistically significant at the $1 \%$ level. 
paired comparisons of market-adjusted stock returns between the two samples. Financial statement measures of performance (return on average assets) do not show a significant difference between the forcedturnover and matched-sample firms. Firms in the forced-turnover and matched samples are of comparable size as measured by the market value of equity. Using sales as a measure of size indicates that turnover firms are significantly larger than matched-sample firms. Therefore, depending on our proxy for firm size and performance, the forced-turnover sample appears to be larger and to have performed worse prior to CEO turnover than the matched sample. We control for the potential size and performance differences by including sales and preturnover stock returns in the empirical analysis that follows.

The ownership structure and corporate governance characteristics of directors in the turnover and matched samples are also shown in table 1 . The percentage of equity ownership does not differ significantly between the forced-turnover and matched samples for both affiliated and independent outside directors based on the preturnover proxy statements. The percentage of equity ownership among insiders, however, is significantly greater in the matched-sample firms. The preturnover board composition in the forced-turnover sample is similar to that of the matched sample with approximately $29 \%$ management, $23 \%$ affiliated outsiders, and $48 \%$ independent outsiders. ${ }^{16}$

Interestingly, the number of committee seats held by independent outsiders is significantly higher in the forced-turnover firms than in the matched-sample firms. This could be due to the size differences between the two samples as larger firms tend to have more committees. The number of other directorships is significantly greater for affiliated outside directors in the forced-turnover firms relative to the matchedsample firms. If these other directorships represent other opportunities for these directors, they may be more willing to challenge managers. The average age and tenure for all directors does not vary significantly between the matched sample and forced-turnover sample prior to turnover.

\section{Analysis of Director Departures}

\section{A. Director Departure Following Forced CEO Turnover}

Although numerous studies examine CEO turnover, few studies examine director turnover and its relation to CEO turnover. Studies by Gil-

16. Byrd and Hickman (1992) document 37.5\% insiders, $23.3 \%$ affiliated outsiders, and $39.2 \%$ independent outsiders in their sample. We include family members and former employees in the affiliated outside group while Byrd and Hickman include these individuals in their insider group. We identify more independent outsiders than Byrd and Hickman but our count is consistent with Booth and Deli (1996), who classify $46.7 \%$ directors as independent outsiders. 
son (1990) and Kini, Kracaw, and Mian (1995) suggest that director turnover is positively related to CEO turnover when CEO turnover is the result of bankruptcy proceedings, private reorganizations, and takeovers. In both studies, the authors suggest that increased director turnover is the consequence of directors being disciplined for poor performance. However, disciplinary actions initiated by bankruptcy proceedings, private reorganizations, and takeover markets may signal the failure of internal control mechanisms. Therefore, it is not surprising that these disciplinary actions extend beyond senior managers to include members of the board of directors. Absent external pressures, there is little evidence of director turnover following CEO turnover. For example, Hermalin and Weisbach (1988) examine changes in board composition over 13 years for a sample of 142 firms and find no evidence that outside directors are more likely to leave the board following CEO turnover.

1. Likelihood of director departure. Assuming the forced removal of a CEO indicates that internal control mechanisms are functioning effectively, directors who participate in a CEO's removal should be less likely (or at least no more likely) to experience turnover themselves if the director labor market rewards these directors. According to Fama (1980) and Fama and Jensen (1983), by signaling to shareholders and labor markets their willingness to discipline a CEO, these directors demonstrate their concern about the performance of the firm and enhance their reputations as effective monitors.

An alternative argument is that the forced removal of a CEO is symptomatic of ineffective monitoring. We abstract from this alternative interpretation by including the set of matching firms that perform similarly to the forced-turnover sample firms in our analysis. ${ }^{17}$ Using a matched sample allows us to assume that the boards forcing CEO turnover are, at a minimum, more effective monitors than their matchedsample counterparts. ${ }^{18}$

Still another argument is that the culture in the modern corporate board discourages criticism and dissent (Jensen 1993). Lorsch and MacIver (1989, p. 17) note that "many directors feel they serve at the

17. Although table 1 documents a significant difference between stock returns for the forced-turnover and matched-sample firms, we find no significant difference in firm performance when measured as average return on assets. Recent research (Weisbach 1988; Murphy and Zimmerman 1993; Hermalin and Weisbach 1998) suggests that accounting measures of performance are better predictors of management changes than are stock returns and, therefore, may be a more useful benchmark for the board of directors when evaluating CEOs. Therefore, we argue that we are effectively controlling for the observed inverse relationship between firm performance and CEO or director turnover.

18. An alternative argument regarding the matched-sample firms is that no forced turnover occurs because management is entrenched. This interpretation further supports the argument that at a minimum, the forced-turnover-sample firm directors are more effective monitors than the matched-sample directors. 
pleasure of the CEO." A new CEO may seek to replace those directors that force CEO turnover with directors that are less likely to challenge his or her decisions. Therefore, according to this argument, directors who participate in the forced removal of a CEO should experience an increased likelihood of departure.

Finally, there are several other potential reasons that are unrelated to the directors' monitoring effectiveness or the culture of corporate boardrooms that may cause directors that force CEO turnover to face an increased likelihood of leaving the board. Some directors may leave the board voluntarily to avoid the increased demands of serving on a board that has removed its CEO or to make room for new directors with a fresh perspective, different skills, or areas of expertise. Regardless of the reason, if the directors that force CEO turnover experience an increased likelihood of departure relative to the directors of matchedsample firms, this would suggest that they suffer adverse consequences for their efforts in removing the CEO.

Table 2 reports the frequency of director departures as well as changes in the status of individual directors. A higher frequency of departure exists for outside directors in the forced-turnover-sample firms relative to the matched-sample firms. Fifty-one percent (94 of 183) of affiliated outside directors and 47\% (172 of 369) of independent outside directors leave the forced turnover sample while only $43 \%$ (82 of 191) of affiliated outside directors and 39\% (152 of 387) of independent outside directors leave the matched sample. In this section, we analyze these departures in an effort to determine whether the difference between the two samples is statistically significant and whether the characteristics of individual directors or firms affect the likelihood of director turnover.

2. Director characteristics and the likelihood of director departure. The corporate governance literature identifies several directorspecific and firm-specific characteristics associated with effective boards. Many of these characteristics are related to the financial or reputational incentives faced by directors. We add to this growing body of literature by examining whether these director or firm characteristics are related to the consequences directors experience after forcing CEO turnover. We estimate a probit model with a dependent variable equal to one if the director leaves the board within 4 years after turnover and zero if the director remains on the board:

\section{Probability that Director Leaves $=$}

$$
f(X, \text { FORCED VOLUNTARY), }
$$

where $X$ includes director age, independence, committee assignments, equity ownership, other directorships held, board size, and postturnover performance as discussed below as well as firm size and preturnover 


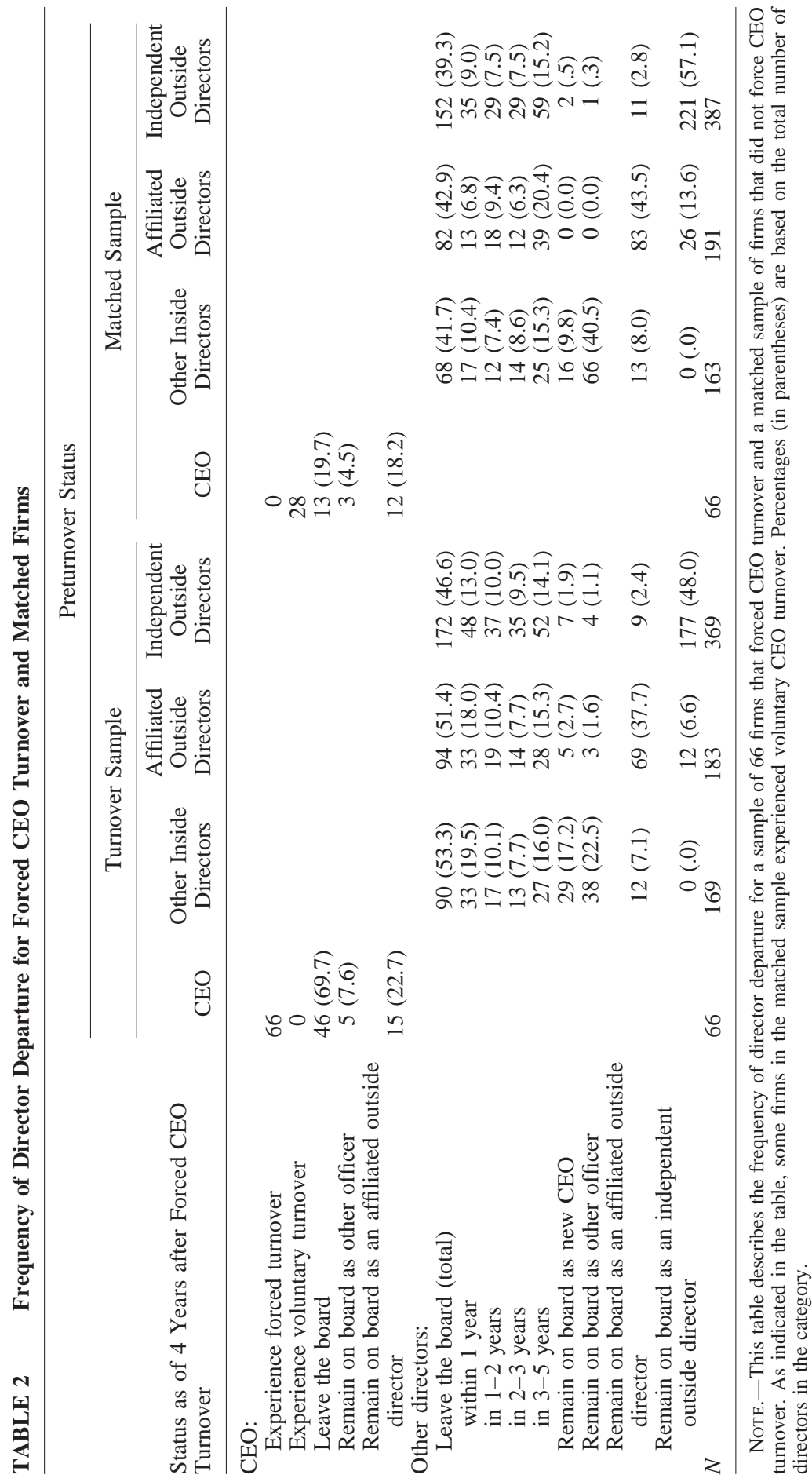


performance control variables. ${ }^{19}$ FORCED equals one if the director is from the forced-turnover sample and zero if the director is from the matched sample. VOLUNTARY equals one if the director is from a matched-sample firm that experiences voluntary CEO turnover and zero if the matched-sample firm does not experience CEO turnover. VOLUNTARY equals zero for all directors in the forced-turnover sample by definition. Therefore, VOLUNTARY should capture the effects of a voluntary CEO turnover while FORCED captures the effects of a forced CEO turnover. In addition to estimating the model as a standard probit model, we estimate the model as a panel with random effects to control for firm effects. ${ }^{20}$

Because older directors are more likely to retire, we expect age to be positively associated with director departure. There is no reason, however, to expect the number of normal retirements to differ systematically between the turnover and matched samples. ${ }^{21}$

Studies by Gilson (1990) and Kini et al. (1995) show that disciplinary actions against the CEO can extend to some directors when the discipline is the result of external pressures. The same may be true when the discipline is internal. Affiliated outside directors, including relatives of top managers or retirees of the firm, tend to be more closely aligned with the CEO. Therefore, the discipline of a forced CEO turnover may also extend to affiliated outside directors, leading to an increased likelihood of their departure from the board following forced CEO turnover. Similarly, directors' committee assignments may indicate how closely aligned they are with senior managers. We distinguish between decision-making and monitoring committees because members of a decision-making committee may have a greater impact on firm performance and may therefore share responsibility and accountability with senior managers to a greater extent than directors that are not members of decision-making committees. ${ }^{22}$ This close alignment

19. The characteristics that determine whether a director becomes the new CEO may differ systematically from the characteristics that determine whether a director that does not become the CEO remains on the board. Therefore, we exclude those directors that become the CEO from this analysis. Table 2 indicates that 12 outside directors become $\mathrm{CEO}$ in the forced-turnover sample. In the matched sample, two outside directors become CEO.

20. Another way to control for firm effects is to estimate a fixed-effects model. However, those variables that do not vary across directors within a firm (sales, board size, stock returns, FORCED, VOLUNTARY) would be perfectly correlated with the effects.

21. To determine the sensitivity of our results to how we control for age, we reestimate our results by excluding all outside directors who are older than 65 prior to the turnover date. We choose a preturnover age of 65 since the normal age (per proxies) for mandatory director retirement is between 70 and 72 . The results for young outside directors are consistent with the results for all outside directors except that the significance of the equityownership variable in the forced-turnover sample is sensitive to the inclusion of random effects.

22. In an analysis of board committee structure, Klein (1998) distinguishes between board committees that are involved in the firm's strategic decision-making process and 
and the impact that the directors' decisions may have on firm performance may cause these directors to be faced with an increased likelihood of leaving the board following CEO turnover in the forced-turnover sample.

Yermack (1996) and Eisenberg et al. (1998) find a negative relation between board size and firm performance, suggesting that smaller boards perform more effectively than larger boards. They attribute these results to the communication and decision-making problems associated with large groups. Directors that sit on large boards, therefore, may be more inclined to resign from the board than directors that sit on small boards.

Agency theory suggests that we should observe greater equity ownership for directors that remain after forced CEO turnover relative to directors that leave. ${ }^{23}$ Several authors have argued that directors with significant equity stakes take a more active interest in monitoring senior managers. ${ }^{24}$ It is reasonable, therefore, to expect that these directors are also less likely to leave the board voluntarily. Moreover, it will be more difficult for a CEO to pressure these directors to leave the board.

Finally, a director's decision-making expertise may affect the likelihood of his or her leaving the board following CEO turnover. Unfortunately, it is difficult to measure an individual director's decisionmaking expertise, especially when they are working within a group. However, one indicator of a director's decision-making expertise is his service on other boards. If directors are chosen for their decisionmaking expertise, then the number of other directorships held by a director may be a reasonable proxy for the director's decision-making expertise (Shivdasani 1993). At the same time, however, it may be a measure of the demands placed on his time (Core, Holthausen, and Larcker 1999).

A measure of the board's aggregate decision-making expertise is the success of the replacement CEO. We expect a director's decision to participate in the forced removal of a CEO to enhance his reputation as a decision-making expert only if it is perceived to be a good decision. Directors that make good replacement decisions should generate above-average market-adjusted stock returns for the firm in the 1-year

board committees that primarily perform a monitoring function. She defines decision-making committees to be finance and strategic-planning committees and monitoring committees to be audit, compensation, and nominating committees.

23. Equity ownership by individual directors includes shares held by the director with sole voting and investment power and shares held by immediate family members, including trusts for children. Shares that can be acquired by exercising stock options are also included. Similar results are found when shares that can be acquired by exercising stock options are excluded from our measure of share ownership.

24. Empirical evidence tends to support this claim. See, e.g., Shivdasani (1993). 
period after turnover. ${ }^{25}$ Therefore, if the firm's performance improves after CEO turnover, we expect the board's decision to remove the CEO to be viewed favorably and the directors on those boards to be less likely to leave the firm after turnover.

If the new CEO is an outsider, he may be more likely to install his own board. Some evidence (Cannella and Lubatkin 1993; Parrino 1997) suggests that hiring a CEO from outside the firm signals to the market that a firm wants to institute fundamental changes in how it operates. Helmich and Brown (1972) and Wiersema (1992) find that the rate of strategic change and the rate of organizational change are greater following outside appointments. To capture the potential effect of an outside replacement on director turnover, we include a dummy variable in the analysis of the forced turnover sample.

\section{B. Empirical Results for the Likelihood of Director Departure}

We estimate three versions of equation (1). First, we estimate the model for all outside directors in the combined samples and include the FORCED and VOLUNTARY dichotomous variables to determine whether forced and/or voluntary CEO succession affects the likelihood of outside director succession during the following 4-year period. Next we estimate the model separately for the forced-turnover and matched samples to determine whether the firm and director characteristics have different influences on outside director succession for the two samples.

Except for the stock-return variables, all variables are measured just prior to the CEO turnover date for both the forced-turnover and matched samples. Because table 1 indicates significant differences between the forced-turnover and matched-sample firms for total sales and average annual market-adjusted stock returns, we include a control for firm size and firm performance. ${ }^{26}$

1. Results for all outside directors. Table 3 reports results of estimating equation (1) for all outside directors in the combined sample, the forced-turnover sample, and the matched sample, respectively. The first column for each sample shows the results of estimating equation (1) for all outside directors without firm effects and the second column reports results with random effects. As expected, age is an important

25. Longer-term measures of performance (e.g., 2-year and 4-year market-adjusted returns) and accounting measures of performance (e.g., return on average assets) yield results similar to those found using 1-year returns.

26. To determine whether our results are sensitive to differences in preturnover performance, we reestimated equation (1) using the matched sample firms that performed poorly (worse than the market) during the 2-year preturnover period and their corresponding forced-turnover firms. These two sets of firms performed similarly (no significant difference) during the preturnover period. The probit results are similar to those shown in table 3 and are available from the authors. 


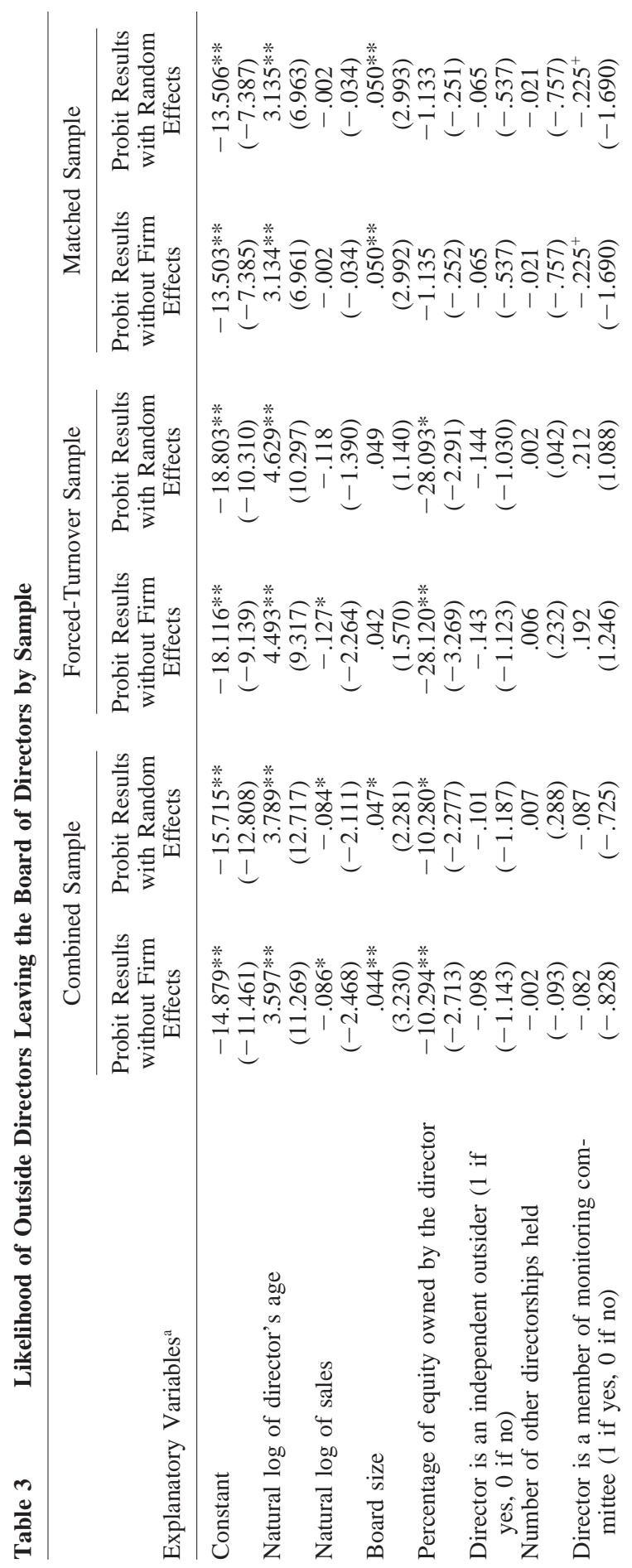




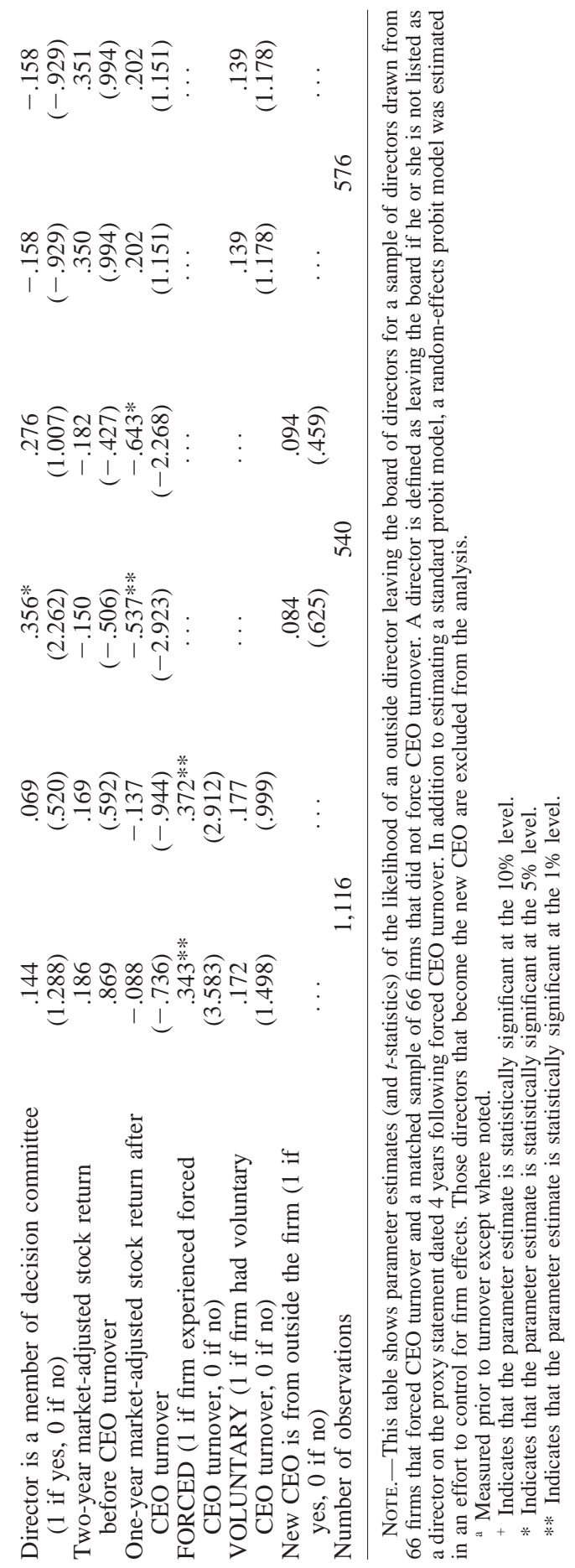


explanatory variable and significantly increases the likelihood that an outside director will leave the board independent of sample or specification.

Directors of larger firms, as indicated by the natural log of sales, are less likely to leave the board in the combined sample, suggesting that these directors are reluctant to give up the prestige associated with serving on the board of a large firm. As argued by Kaplan and Reishus (1990), firm size may increase the opportunities available to directors for other outside directorships. Directors may be less inclined to resign from the board of a large firm because of the loss in reputational capital they would experience. Column 3 in table 3 indicates that this result is driven by the forced-turnover sample, although the significance of this variable is sensitive to the inclusion of random effects.

In the combined sample results, the coefficient associated with board size is positive and statistically significant, indicating that large boards have a higher departure rate than small boards. Yermack (1996) argues that small boards perform better than large boards because they have fewer decision-making and communication problems. Based on this argument, it is not surprising that smaller boards also tend to have lower director departure rates. Further, board size is not significant in explaining director departure in the forced-turnover sample. The directors in this sample were able to overcome at least some decision-making and communication problems, as evidenced by their ability to force CEO turnover. The positive and significant coefficient associated with board size in the matched sample is consistent with Yermack's argument that larger boards experience more difficulties in accomplishing firm objectives.

The coefficient associated with equity ownership is negative and statistically significant in the combined sample. In the forced-turnover sample, the coefficient on the percentage of equity owned by a director is nearly three times larger than that for the combined sample. The coefficient is not statistically significant (at conventional levels) for the matched sample. The results suggest that a director serving on a board that forces CEO turnover will experience a lower probability of turnover if the director holds a higher percentage of equity ownership relative to other directors serving on that board. Therefore, equity ownership provides some protection against the potential adverse consequences of forcing CEO turnover. ${ }^{27}$

In each of the three versions of equation (1), we find little evidence that the number of other directorships held or a director's independence

27. The results do not suggest, however, that directors in the forced-turnover sample have greater equity ownership than directors that do not force CEO turnover. Note in table 1 that there are no significant differences in equity ownership for outside directors between the forced-turnover and matched-sample firms. 
influences the likelihood that a director leaves the board. There is some evidence, however, that those directors that were members of a decision-making committee are more likely to leave the board of a forcedturnover firm. ${ }^{28}$ This is consistent with the hypothesis that directors that serve on a decision-making committee may share accountability with senior managers to a greater extent than directors that are not members.

Firm performance appears to have little impact on director departure in the combined sample. When the sample is limited to the forcedturnover sample, however, the results suggest a lower probability of outside-director departure if the firm experiences good performance after forcing CEO turnover. ${ }^{29}$ This is consistent with outside directors being valued for their decision-making expertise. If the firm performs poorly after the board of directors forces CEO turnover, either the decision to fire the CEO or the replacement decision is perceived poorly, and the participating outside directors are more likely to leave the board. On the other hand, if the firm performs well after a forced CEO turnover, the decision is viewed favorably and the directors are more likely to remain on the board. For the matched-sample directors, on the other hand, performance has no significant impact on the likelihood that outside directors leave the board.

In the combined sample, the coefficient associated with a forced turnover is positive and statistically significant, indicating that directors in the forced-turnover sample experience an increased likelihood of leaving the board. As noted previously, the turnover process itself may result in some restructuring of the board independent of the type of turnover. We attempt to control for a new CEO installing his or her own board by including a dummy variable for voluntary turnovers. The variable is not statistically significant (at conventional levels) in all regressions, suggesting that these directors do not experience an increase in the likelihood of leaving the board following a voluntary CEO turnover. This latter result is consistent with Hermalin and Weisbach (1988) who find no relationship between outside-director turnover and CEO turnover. Our results suggest that those directors who force a CEO to resign suffer adverse consequences for their efforts. The directors that participate in the forced removal of a CEO are more likely to leave the board than their matched-sample counterparts, even relative to directors that sit on the board of a firm that experiences voluntary CEO turnover.

28. It should be noted, however, that the coefficient associated with this variable is sensitive to the inclusion of random effects.

29. One potential concern with these results is that some of the directors leave the board before the end of the year that follows CEO turnover. Therefore, the departure of these directors should not be related to the postturnover performance. To determine whether the results are sensitive to the inclusion of these directors, we estimated equation (1) excluding directors that leave the board within 1 year following forced CEO turnover. The results of this specification of the probit model are very similar to those reported in table 3 . 


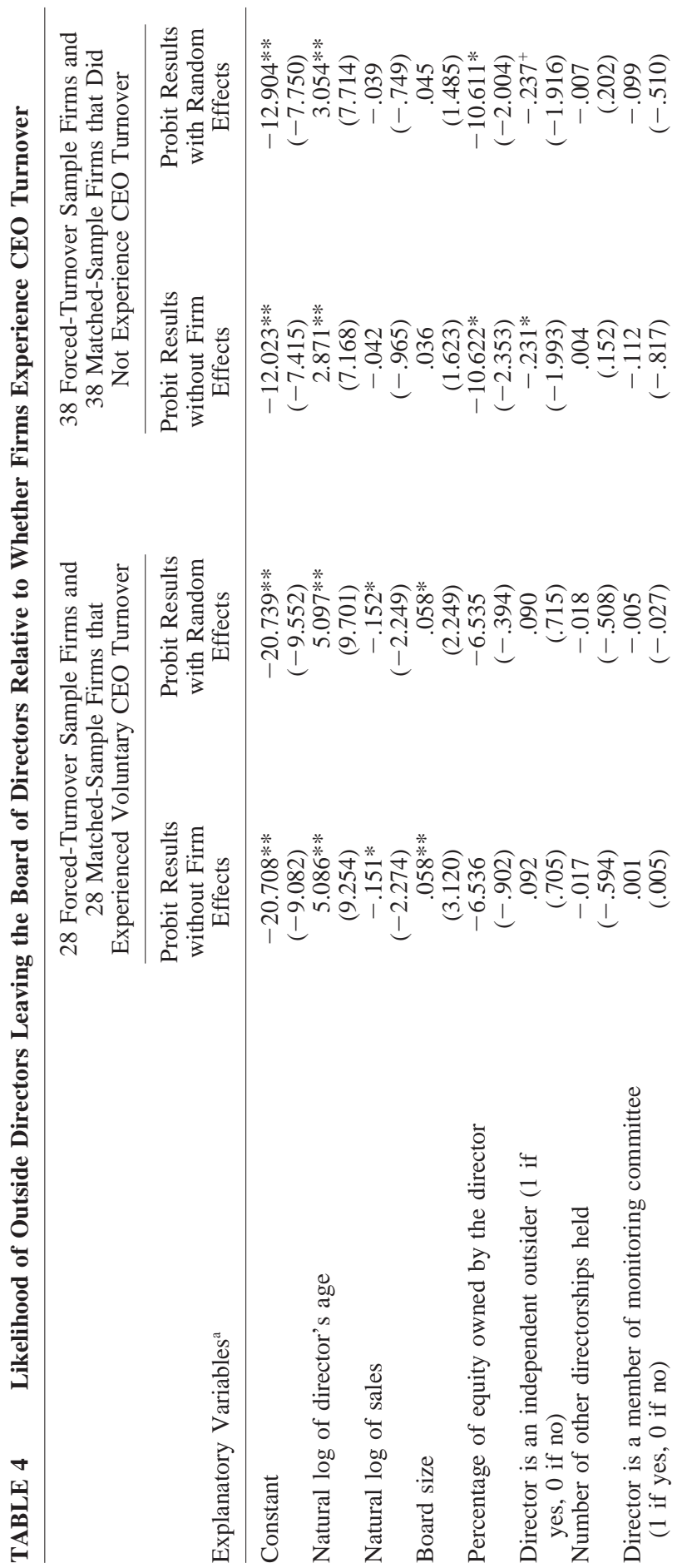




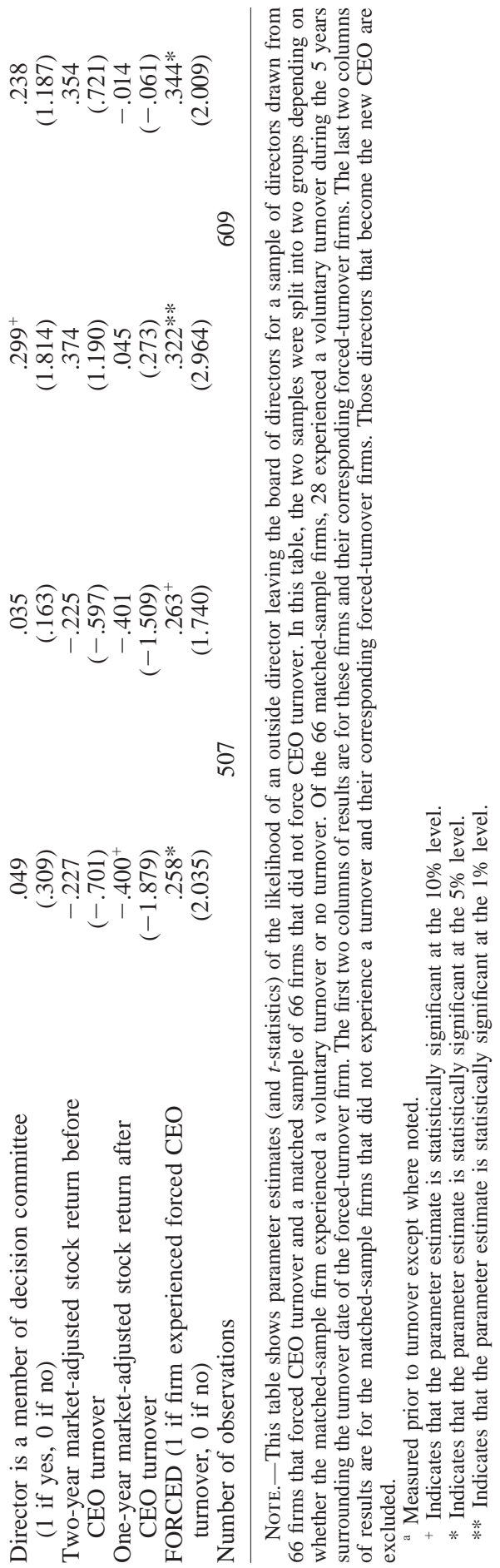


2. Forced CEO turnover versus voluntary CEO turnover. A more rigorous test to control for a general turnover effect is to separate our matched sample into the 28 firms experiencing voluntary CEO turnover and the 38 firms experiencing no turnover. We report regression results for the two samples and their corresponding forced-turnover-sample firms in table 4 . We continue to find a higher probability of outsidedirector turnover in the forced-turnover-sample firms relative to the matched-sample firms regardless of whether the matched-sample firms experience voluntary or no turnover.

Overall, the probit results suggest that forced CEO turnover is associated with greater uncertainty for an outside director in terms of his or her tenure on the board. Specifically, firing a CEO appears to result in adverse consequences for a director. Within the forced-turnover sample, differences in firm size, equity ownership, committee memberships, and firm performance are significant in determining the likelihood of departure. In particular, the results for the forced-turnover sample suggest that those directors that are closely aligned with the $\mathrm{CEO}$, as evidenced by their service on a decision-making committee, and own little equity are more likely to leave the board. Moreover, a director is more likely to leave if the CEO turnover or replacement decision is perceived by the market to be a poor one, that is, if the firm performs poorly after CEO turnover.

An alternative interpretation of the results is that outside directors of firms that force CEO turnover are more inclined to leave the board voluntarily than the outside directors of firms that experience voluntary CEO turnover or no CEO turnover. Unfortunately, data are not available to distinguish between those directors in the forced-turnover sample that participated in the forced removal of the CEO and those that supported the CEO. The results of voting by the board are not made public and only rarely are the opinions of individual directors made public. In addition, reasons for director resignations are rarely made public, making it difficult to determine whether an individual director's departure from a board is voluntary or is the result of pressure from the CEO or other directors. ${ }^{30}$

Similarly, one could argue that the appointment of a new CEO may require directors with a different set of skills and that forced CEO turnover may result in more substantial restructuring of the board than voluntary CEO turnover. Therefore, we cannot conclude that forcing CEO turnover leads to outside directors being punished in the market for their services. However, we can conclude that outside directors tend

30. In some cases, proxy statements announce a director's death or reaching the mandatory retirement age. However, the death rate or incidence of mandatory retirement of directors should not systematically differ between the forced turnover and matched samples. Therefore, we do not attempt to control for these types of departure. 
to suffer adverse consequences in the form of a higher probability of departure from the board after forcing CEO turnover. In the next section we analyze whether outside directors that force CEO turnover experience any consequences in terms of their service on other boards.

\section{Analysis of Other Directorships}

The second potential consequence for a director forcing CEO turnover is a change in the opportunities available for other directorships outside of the firm. Extant evidence suggests that bad managers and bad directors lose directorships. For example, Kaplan and Reishus (1990) report that poorly performing managers hold fewer directorships than managers of other firms. Gilson (1990) finds that directors who leave the board of a financially distressed firm tend to lose other directorships. To our knowledge, however, no study has examined whether directors that perform effectively experience any significant consequences in terms of the other directorships they hold.

\section{A. Changes in Other Directorships}

By forcing CEO turnover, directors send an unambiguous signal of their willingness to monitor and discipline senior managers. Therefore, according to the Fama and Jensen (1983) argument, we would expect these directors to experience an increase in the number of other directorships they hold as compared to the number of other directorships held by the directors of matched-sample firms.

The alternative argument, however, is that managers have significant control over the director selection process and are reluctant to appoint directors that might challenge them. Mace (1986) argues that outside directors are often friends and associates of senior managers and that outside directors are selected for their ability to advise senior managers, not their willingness to challenge senior managers. Therefore, according to this argument, we should observe a decrease in the number of other directorships held by directors that force CEO turnover relative to their matched-sample counterparts.

As in the previous section, we expect age to be related to changes in the number of other directorships because older directors are more likely to retire and less likely to accept additional directorships. There is no reason, however, to expect the number of normal retirements to differ systematically between the turnover and matched samples.

We also find in the previous section that those directors remaining on the board of a firm that forced CEO turnover tend to be those that own substantial equity in the firm, that were not closely aligned with the outgoing CEO, and whose firms performed relatively well following the CEO's removal. We include a variable, STAY (one if director stays on board, zero if not), that should capture the effect of these direc- 
tors having a higher probability of remaining on the board after forcing CEO turnover. If the director labor market rewards directors that perform well, as suggested by Fama and Jensen (1983), then these directors should face an increased likelihood of gaining additional directorships. If the director labor market does not reward good performance, then these directors should not gain any more directorships than those that left the board or the directors in the matched sample.

Large firms tend to have more contracting relations with other firms than small firms, thus there may be more opportunities for other directorships for directors that sit on large firms' boards. In addition, the reputational capital associated with serving on the board of a large firm may lead to additional directorship opportunities (see, e.g., Booth and Deli 1996).

Finally, the directors' decision-making expertise may affect the likelihood of their gaining or losing directorships. As in the previous section, the number of other directorships held by a director may be a reasonable proxy for the director's decision-making expertise and the success of the replacement CEO may be a measure of the board's aggregate decision-making ability.

\section{B. Empirical Results for Changes in Other Directorships}

Table 5 summarizes the number of directorships gained and lost in the 4-year period following forced CEO turnover. The number of directorships gained ranges from zero to seven. The number of directorships lost ranges from zero to eight. About 58\% (158 of 274) of the forcedturnover-sample directors that remain on the board gain new directorships while about 56\% (154 of 274) lost at least one directorship. Of the matched-sample directors that remain on the board, about 50\% (172 of 342) gain at least one new directorship while about 58\% (197 of 342) lose a directorship.

Of those directors that leave the board, we were able to find complete directorship information for $51 \%$ (136 of 266) of the forced-turnoversample directors and $48 \%$ (112 of 234) of the matched-sample directors. Of these, $48 \%$ (65 of 136) of the forced-turnover-sample directors and $43 \%$ (48 of 112) of the matched-sample directors gained new directorships. In addition, at least 69\% (183 of 266) of the forced-turnover sample directors and at least $67 \%$ (156 of 234) of the matched-sample directors that leave the board lost a directorship.

To examine formally whether directors in the forced-turnover sample are more likely to gain or lose directorships, we estimate two probit models. The first model has a dependent variable equal to one for directors that gain a new directorship in the 4-year period following forced CEO turnover and zero for directors that did not gain any new directorships. The second model has a dependent variable equal to one for directors that lose a directorship in the 4-year period following forced 
TABLE 5 Changes in Directorships Held by Outside Directors of 66 Firms Experiencing Forced CEO Turnover and 66 Matched Firms that Do Not Experience Forced CEO Turnover

\begin{tabular}{|c|c|c|c|c|}
\hline & \multicolumn{2}{|c|}{$\begin{array}{l}\text { Directors that } \\
\text { Remain on Sample } \\
\text { Firm's Board }\end{array}$} & \multicolumn{2}{|c|}{$\begin{array}{l}\text { Directors that Leave } \\
\text { Sample Firm's } \\
\text { Board }\end{array}$} \\
\hline & $\begin{array}{l}\text { Forced- } \\
\text { Turnover } \\
\text { Sample }\end{array}$ & $\begin{array}{l}\text { Matched } \\
\text { Sample }\end{array}$ & $\begin{array}{l}\text { Forced- } \\
\text { Turnover } \\
\text { Sample }\end{array}$ & $\begin{array}{l}\text { Matched } \\
\text { Sample }\end{array}$ \\
\hline \multicolumn{5}{|l|}{ Other directorships acquired: } \\
\hline Zero & 116 & 170 & 71 & 64 \\
\hline One & 82 & 82 & 26 & 25 \\
\hline Two & 43 & 51 & 22 & 14 \\
\hline Three & 16 & 23 & 11 & 8 \\
\hline More than three & 17 & 16 & 6 & 1 \\
\hline \multicolumn{5}{|c|}{ Not found on Lexis-Nexis or volume } \\
\hline 2 of the $S \& P$ Register & . . & $\cdots$ & 130 & 122 \\
\hline \multicolumn{5}{|l|}{ Other directorships lost: } \\
\hline None to lose & 36 & 47 & 45 & 41 \\
\hline Zero & 84 & 98 & 31 & 30 \\
\hline One & 80 & 100 & 78 & 57 \\
\hline Two & 39 & 60 & 35 & 50 \\
\hline Three & 22 & 19 & 28 & 17 \\
\hline More than three & 13 & 18 & 42 & 32 \\
\hline \multicolumn{5}{|c|}{$\begin{array}{l}\text { Unable to verify any lost director- } \\
\text { ships using volume } 1 \text { of the } S \& P\end{array}$} \\
\hline Register & ... & $\cdots$ & 7 & 7 \\
\hline Number of directors & 274 & 342 & 266 & 234 \\
\hline
\end{tabular}

NoTE. - This table describes the directorships acquired and directorships lost for outside directors in a sample of 66 firms that forced CEO turnover and a matched sample of firms that did not force CEO turnover. Directorships acquired and lost were determined by comparing the directorships held by individual directors prior to forced CEO turnover (as indicated in the preturnover proxy statement) to the directorships held by the directors 4 years after the forced CEO turnover. The postturnover directorships are identified in sample firms' proxy statements for those directors that remain on the board. For those directors that leave the board, we searched both Lexis-Nexis and volume 2 of the $S \& P$ Register for information about the directorships held by individual directors. For those directors that are not found in either Lexis-Nexis or volume 2 (Executives and Directors) of the $S \& P$ Register, we searched volume 1 (Corporations) of the $S \& P$ Register in an effort to verify lost directorships. Those directors that become the new CEO are excluded from the analysis.

\section{CEO turnover and zero for directors that did not lose any directorships. This is similar to the approach taken by Kaplan and Reishus (1990). ${ }^{31}$}

31. An alternative to Kaplan and Reishus's (1990) methodology is to estimate one model with a dependent variable equal to one if the director's net change in directorships is positive (zero if the net change is not positive) and another model with a dependent variable equal to one if the director's net change in directorships is negative (zero if the net change is not negative). The results of using this methodology are similar to the results given in tables 6 and 7. Still another approach would be to estimate an ordered logit model with a dependent variable indicating whether a director is a net gainer of directorships, experiences no change in directorships, or is a net loser of directorships. This approach yields poor results because the explanatory variables do not have the same impact on new directorships as they do on lost directorships. In addition, many directors do not have any other directorships prior to CEO turnover, making it inappropriate to include them in any analysis that includes lost directorships. 
Because of differences in the way directorship data were collected for the directors that remain on a sample firm's board and directors that leave a sample firm's board, we estimate five versions of each probit model. First we estimate the model for all directors. Next, we estimate the model separately for the turnover and matched samples. Finally, we estimate separate models for those directors that remain on a sample firm's board and those that leave a sample firm's board.

One could argue that the exclusion of directors who cannot be found will bias our results. The expectation would be to observe a positive coefficient estimate for the FORCED variable if a disproportionately large fraction of the directors who depart firms with forced turnover were excluded from the analysis. However, as noted in table 5, we are unable to locate directors in Lexis-Nexis or volume 2 of the $S \& P$ Register for $52 \%$ of the directors that leave the matched-sample firms versus $49 \%$ of the directors that leave the forced-turnover-sample firms. Therefore, the potential bias associated with missing directorship data would not explain the reported results.

1. Results for new directorships. The results of estimating the probit model for new directorships are given in table 6. Only those directors for whom complete directorship data were available are included in this analysis. Therefore, many of the directors that left the board of a sample firm are excluded. The negative coefficient on the natural $\log$ of a director's age indicates that older directors are less likely to acquire a new directorship. Interestingly, the more directorships a director holds, the more likely he or she is to acquire an additional directorship. Further, those that remain on the board of a sample firm are more likely to acquire an additional directorship than those that leave the board of a sample firm, as indicated by the positive coefficient on the STAY variable.

The coefficient on the FORCED variable is positive and significant in the probit results for all directors, suggesting that those directors that participate in the forced removal of a CEO are rewarded in the market for their services as a director. However, when we estimate separate models for directors that remain on the board and those that leave the board, we find that the coefficient on FORCED is only significant for directors that remain on a sample firm's board. The directors that leave the board of a firm that forced CEO turnover are no more (or less) likely to acquire additional directorships than directors that leave the board of a matched-sample firm. Further, within the matched sample, there is no significant difference in the likelihood of gaining additional directorships for directors that remain on the sample firm's board and those that leave. Within the forced-turnover sample, directors that remain on the sample firm's board are significantly more likely to acquire additional directorships. Therefore, although there is some evidence suggesting that directors are rewarded for disciplining a poorly per- 


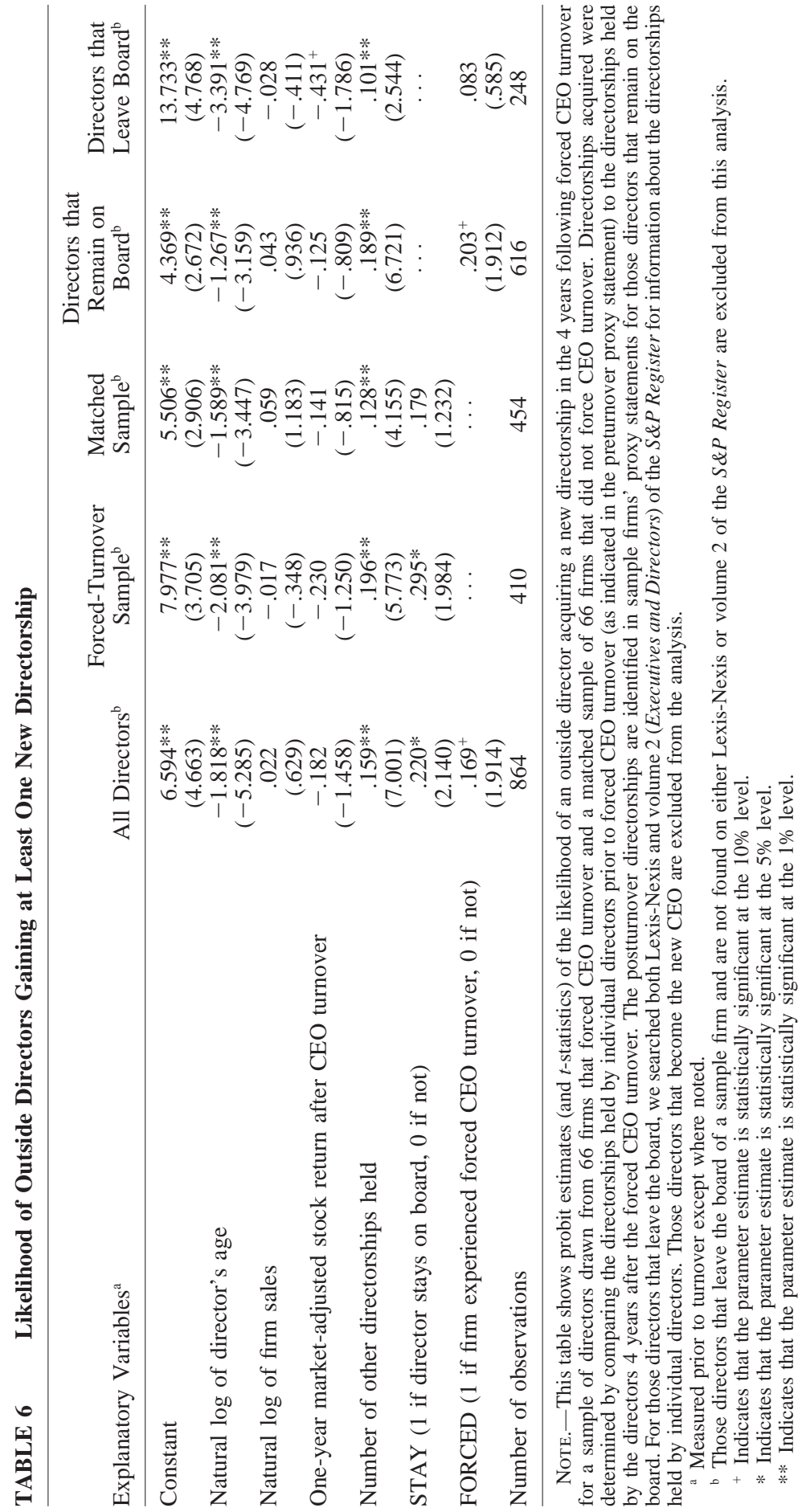


forming $\mathrm{CEO}$, these rewards only extend to those directors that continue to serve on the firm's board. ${ }^{32}$

2. Results of lost directorships. The results of estimating the probit model of lost directorships are given in table 7. Only those directors that held at least one other directorship prior to forced CEO turnover are included in this analysis. The positive coefficient on the natural log of a director's age indicates that older directors are more likely to lose directorships. However, this result applies only to directors that leave the board of a sample firm. Also, the more directorships a director holds, the more likely he or she is to lose a directorship. Those directors that remain on a sample firm's board were less likely to lose directorships than directors that leave the board of a sample firm for both the turnover and matched samples. Finally, our results suggest that the directors that forced CEO turnover are no more (or less) likely to lose a directorship than their matched-firm counterparts, regardless of whether they remain on the board or leave the board.

It is interesting to note that the coefficient on the log of firm sales is negative for those directors that remain on a sample firm's board and positive for those directors that leave the board. These results suggest that directors of large firms are less likely to lose other directorships than directors of small firms as long as they remain on the board. When a director of a large firm leaves the board, he is more likely to lose other directorships than a director that leaves the board of a small firm. This is consistent with the directors of large firms enjoying greater prestige and reputations than directors of small firms.

Overall, our results suggest that participating in the forced removal of a CEO does not lead to a director losing other directorships regardless of whether the director remains on the board or leaves the board after the CEO turnover. The results for other directorships gained suggest that directors are rewarded for disciplining a poorly performing CEO if the directors continue to serve on the firm's board.

\section{Conclusion}

By examining the determinants of whether a director leaves the board in the 4-year period following forced CEO turnover, we provide evidence on whether forced CEO turnover affects director tenure. By examining changes in the number of other directorships held, we provide evidence of whether directors that force CEO turnover experience changes in other directorships that differ from their matched-firm counterparts.

We find evidence suggesting that outside directors of firms that force

32. Similar results are found when those directors over the age of 65 at the time of forced CEO turnover are excluded from the analysis shown in table 6. 


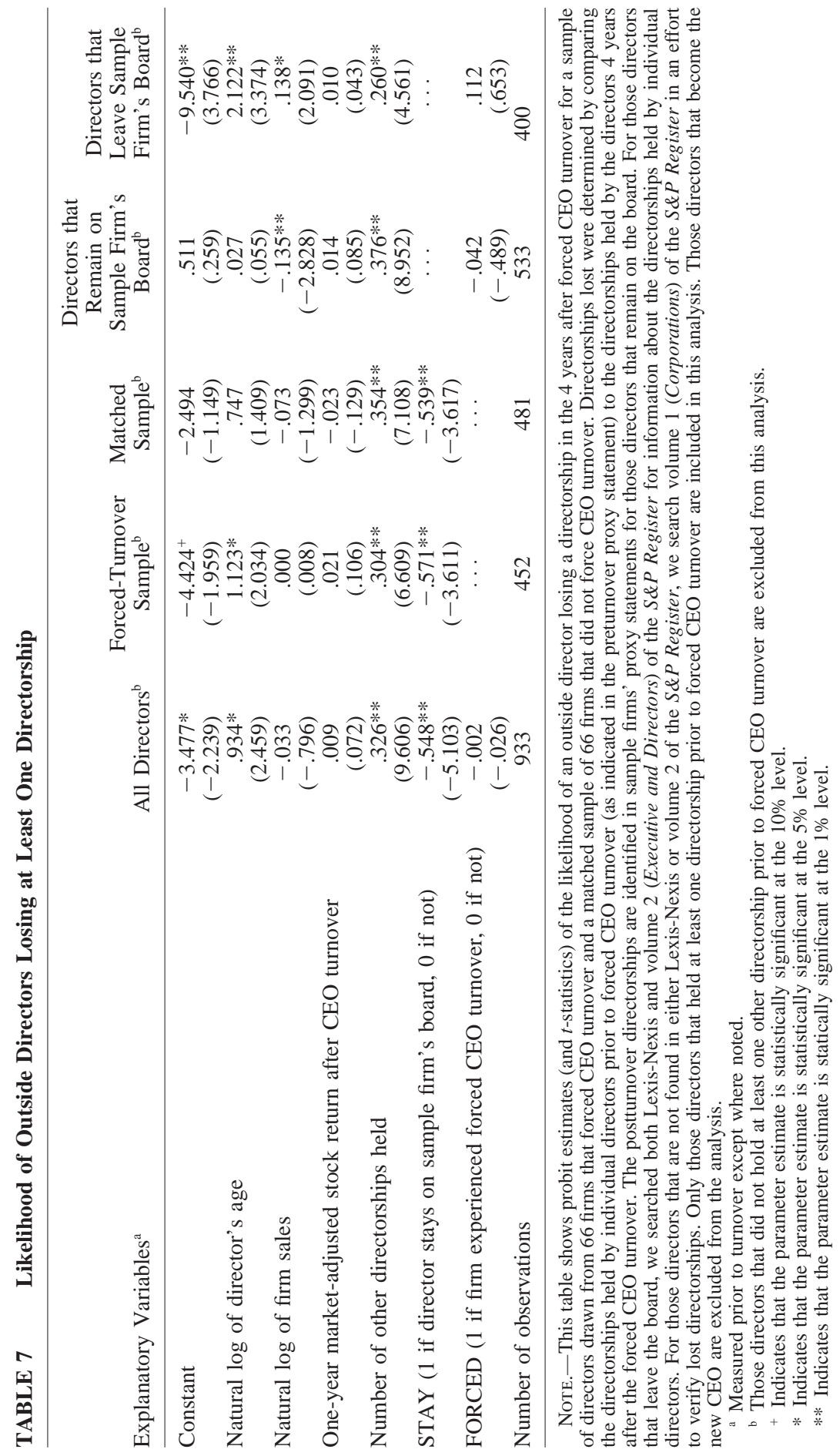


CEO turnover are more likely to leave the firm than outside directors of firms that do not force CEO turnover, even those that experience voluntary CEO turnover. However, it tends to be those directors that were closely aligned with the outgoing CEO, as evidenced by their service on a decision-making committee, and own little equity that are most likely to leave the board of a firm that forced CEO turnover. Further, the directors of firms that perform poorly following forced CEO turnover are more likely to leave the firm.

We also find evidence that those directors remaining on the board of a firm that forced CEO turnover are rewarded in the market for their services as a director. These directors tend to be those that were not closely aligned with the outgoing CEO, owned substantial equity in the firm, and whose firms performed well following the forced CEO turnover. These directors are more likely to gain at least one new directorship than those directors that remain on the board of a matchedsample firm. These directors are also no more likely to lose other directorships. The evidence is consistent with the market for outside directors rewarding those directors that remove a poorly performing $\mathrm{CEO}$ and make good replacement decisions.

One interpretation of the overall results is that effective monitoring of a poorly performing CEO is a risky gamble involving two decisions. First, directors must determine whether it is necessary to force CEO turnover, and then directors must choose the successor. Our results suggest that directors only receive rewards for their efforts if they make both decisions successfully. This may explain the anecdotal evidence presented by Lublin and Duff (1995) that many directors are reluctant to remove a poorly performing CEO.

\section{References}

Allgood, S. A., and Farrell, K. A. 2000. The effect of CEO tenure on the relation between firm performance and turnover. Journal of Financial Research 23 (Fall): 373-90.

Baysinger, B. D., and Zardkoohi, A. 1986. Technology, residual claimants and corporate control. Journal of Law, Economics, and Organization 2 (Fall): 339-49.

Blackwell, D. W., and Farrell, K. A. 1999. Changes in CEO compensation and firm performance following CEO turnover. Working paper. Lincoln: University of Nebraska.

Booth, J. R., and Deli, D. N. 1996. Factors affecting the number of outside directorships held by CEOs. Journal of Financial Economics 40 (January): 81-104.

Brickley, J. A.; Coles, J. L.; and Terry, R. L. 1994. Outside directors and the adoption of poison pills. Journal of Financial Economics 35 (June): 371-90.

Brickley, J. A., and James, C. M. 1987. The takeover market, corporate board composition, and ownership structure: The case of banking. Journal of Law and Economics 30 (April): $161-80$.

Byrd, J. W., and Hickman, K. A. 1992. Do outside directors monitor managers? Evidence from tender offer bids. Journal of Financial Economics 32 (October): 195-221.

Cannella, A., Jr., and Lubatkin, M. 1993. Succession as a sociopolitical process: Internal impediments to outside selection. Academy of Management Journal 36 (August): $763-$ 93.

Clark, R. N. 1989. SICs as delineators of economic markets. Journal of Business 62 (January): $17-31$. 
Core, J. E.; Holthausen, R. W.; and Larcker, D. F. 1999. Corporate governance, chief executive officer compensation, and firm performance. Journal of Financial Economics 51 (March): 371-406.

Coughlan, A. T., and Schmidt, R. M. 1985. Executive compensation, management turnover, and firm performance: An empirical investigation. Journal of Accounting and Economics 7 (April): 43-66.

DeFond, M. L., and Park, C. W. 1999. The effect of competition on CEO turnover. Journal of Accounting and Economics 27 (February): 35-56.

Denis, D. J., and Denis, D. K. 1995. Performance changes following top management dismissals. Journal of Finance 50 (September): 1029-57.

Eisenberg, T.; Sundgren, S.; and Wells, M. T. 1998. Larger board size and decreasing firm value in small firms. Journal of Financial Economics 48 (April): 35-54.

Fama, E. F. 1980. Agency problems and the theory of the firm. Journal of Political Economy 88 (April): 134-45.

Fama, E. F., and Jensen, M. C. 1983. Separation of ownership and control. Journal of Law and Economics 27 (June): 301-25.

Gilson, S. C. 1989. Management turnover and financial distress. Journal of Financial Economics 25 (December): 241-62.

Gilson, S. C. 1990. Bankruptcy, boards, banks, and blockholders. Journal of Financial Economics 27 (October): 355-87.

Helmich, D. L., and Brown, W. B. 1972. Successor type and organizational change in the corporate enterprise. Administrative Science Quarterly 17 (September): 371-81.

Hermalin, B. E., and Weisbach, M. S. 1988. The determinants of board composition. RAND Journal of Economics 19 (Winter): 589-606.

Hermalin, B. E., and Weisbach, M. S. 1991. The effects of board composition and direct incentives on firm performance. Financial Management (Winter): 101-12.

Hermalin, B. E., and Weisbach, M. S. 1998. Endogenously chosen boards of directors and their monitoring of the CEO. American Economic Review (March): 96-118.

Huson, M. R.; Parrino, R.; and Starks, L. 2000. Internal monitoring mechanisms and CEO turnover: A long term perspective. Working paper. Austin: University of Texas.

Jensen, M. C. 1993. The modern industrial revolution, exit, and the failure of internal control systems. Journal of Finance 48 (July): 831-80.

Kaplan, S. N., and Reishus, D. 1990. Outside directorships and corporate performance. Journal of Financial Economics 27 (October): 389-410.

Kini, O.; Kracaw, W.; and Mian, S. 1995. Corporate takeovers, firm performance, and board composition. Journal of Corporate Finance 1 (April): 383-412.

Klein, A. 1998. Firm performance and board committee structure. Journal of Law and Economics 41 (April): 275-303.

Lorsch, J. W., and MacIver, E. 1989. Pawns or Potentates: The Reality of America's Corporate Boards. Boston: Harvard Business School Press.

Lublin, J. S., and Duff, C. 1995. How do you fire a CEO? Very, very slowly. Wall Street Journal (January 20).

Mace, M. L. 1986. Directors: Myth and Reality. Boston: Harvard University Press.

Murphy, K., and Zimmerman, J. L. 1993. Financial performance surrounding CEO turnover. Journal of Accounting and Economics 16 (April/July): 273-315.

Parrino, R. 1997. CEO turnover and outside succession: A cross-sectional analysis. Journal of Financial Economics 46 (November): 165-97.

Shivdasani, A. 1993. Board composition, ownership structure, and hostile takeovers. Journal of Accounting and Economics 16 (January): 167-98.

Subrahmanyam, V.; Rangan N.; and Rosenstein, S. 1997. The role of outside directors in bank acquisitions. Financial Management 26 (Autumn): 23-36.

Warner, J. B.; Watts, R. L.; and Wruck, K. 1988. Stock prices and top management changes. Journal of Financial Economics 20 (January/March): 461-92.

Weirsema, M. F. 1992. Strategic consequences of executive succession within diversified firms. Journal of Management Studies 29 (January): 73-94.

Weisbach, M. S. 1988. Outside directors and CEO turnover. Journal of Financial Economics 20 (January): 431-60.

Yermack, D. 1996. Higher market valuation of companies with a small board of directors. Journal of Financial Economics 40 (February): 185-211. 